\title{
Effect of tenidap on cartilage integrity in vitro
}

\author{
John T Dingle, Michael R G Leeming, Jacqueline J Martindale
}

\begin{abstract}
Objectives-The maintenance of articular cartilage integrity during long term treatment with non-steroidal antiinflammatory drugs (NSAIDs) is of clinical importance. These experiments were set up to test the action of tenidap, naproxen, and diclofenac on bovine and porcine cartilage, matrix synthesis, and catabolism.
\end{abstract}

Methods-Short term organ culture techniques were used to determine the effect of interleukin 1 (IL-1) on synthesis and degradation, and the action of tenidap and the other drugs on these parameters. The retention of glycosaminoglycans (GAGs) and the synthesis of GAGs by incorporation of sulphur-35 labelled sulphate was used to determine the chondrocyte metabolic activity.

Results-The action of human recombinant interleukin $1 \alpha(\mathrm{hrIL-1} \alpha)$ in increasing catabolic activity and inhibiting synthetic activity of the animal cartilages was confirmed. Tenidap was shown to give substantial and significant protection against the catabolic effects of hrIL-1 $\alpha$ and, to a lesser degree, against the inhibition of matrix synthesis by the cytokine. Neither diclofenac nor naproxen in doses expected to occur in the synovial fluid showed this action. Tenidap also inhibited the GAG loss from cocultures and, to a moderate degree, reversed the inhibition of synthesis by synovial tissue. Tenidap also stimulated cartilage repair activity during recovery from IL-1 treatment. The optimum concentration of the action against IL-1 was between 5 and $10 \mu \mathrm{g} / \mathrm{ml}$. Above this concentration tenidap itself showed some inhibitory action on GAG synthesis.

Conclusions-Bearing in mind the problems in extrapolating from in vitro work on animal cartilages to humans, it seems possible that tenidap may be useful in decreasing the deleterious action of cytokines such as IL-1 on cartilage integrity during arthritic disease and in stimulating chondrocyte repair processes.

(Ann Rheum Dis 1993; 52: 292-299)

Cartilage chondrocytes maintain a dynamic equilibrium in their extracellular matrix throughout life by synthesising and degrading structural macromolecules. In disease, however, the rate of breakdown may exceed the rate of formation, with net loss of material ensuing. It is now recognised that these processes may be controlled by local cytokine messengers from adjacent cells and tissues of the adult joint. ${ }^{1-4}$ The most extensively studied of these cytokines, interleukin $1 \alpha$ (IL-1 $\alpha$ ), may have a function in controlling articular integrity in inflammatory arthritis and in the slower osteoarthritic process. ${ }^{5-7}$

In rheumatoid arthritis the breakdown of cartilage adjacent to the pannus is thought to be due to proteolytic enzymes secreted by inflammatory cells, by stimulated cells of the invading and proliferating synovium, and by activated chondrocytes. The IL- $1 \alpha$ and other cytokines produced by the inflammatory cells and fibroblasts of the synovium may stimulate cartilage breakdown and inhibit the synthesis of cartilage matrix by indigenous chondrocytes. This inhibition may be more important in the slower processes seen in osteoarthritis, where it is suggested that the local episodic release of cytokines causes a net loss of proteoglycan and, eventually, collagen ${ }^{8-11}$ by inhibiting the normal matrix repair processes. There is clinical and biological evidence that cartilage repair can take place, ${ }^{12}{ }^{13}$ but it is unfortunate that a number of powerful anti-inflammatory drugs which are used in the treatment of arthritic diseases may depress cartilage synthetic activity. ${ }^{14-17}$ It is necessary, therefore, to ensure that new antiinflammatory drugs do not interfere with the normal repair processes. If such drugs could also be shown to decrease the activity of cytokines in causing articular cartilage damage, they could be of substantial value in the long term treatment of patients with arthritis.

The experimental antiarthritic drug tenidap has been shown to lower the production of a number of inflammatory mediators including IL- $1 \alpha .{ }^{18}{ }^{19}$ In the light of these results tenidap was tested in in vitro cartilage organ culture assays to determine its effect on the catabolic and anabolic activity of indigenous chondrocytes. Experiments were also set up using bovine and porcine cartilage to determine whether tenidap was capable of protecting cartilage from the direct activity of human recombinant IL- $1 \alpha$ (hrIL-1 $\alpha$ ) and from the destruction mediated by adjacent synovial tissue.

\section{Patients and methods}

ORGAN CULTURE TECHNIQUES

Techniques were based on the methods of Dingle et al. ${ }^{20}$ Porcine cocultures were set up as described by Fell and Jubb, ${ }^{21}$ whereas bovine cocultures were a development of the method of Dingle. ${ }^{22}$

The porcine cartilage was obtained from the 
chondyles of the metacarpophalangeal joints of adolescent pigs freshly killed at a commercial abattoir. The synovial tissue was obtained from the same joint and chopped into small pieces before use. The cartilage was usually cultured in $4 \times 2 \times 1 \mathrm{~mm}$ segments, six segments being obtained from each pig's trotter. In porcine coculture approximately $5 \mathrm{mg}$ wet weight synovial tissue was used.

The bovine cartilage was obtained from 1 $\mathrm{mm}$ slices of the nasal septum of adult cows freshly slaughtered at an abattoir from which $4 \mathrm{~mm}$ discs or annuli were cut out using a modified commercial leather punch; 150 replicates could be obtained from a single nasal septum. To minimise variability, 10 replicate organ cultures were set up for each treatment. Most experiments used 100-140 organ cultures. For bovine cocultures, annuli ( $4 \mathrm{~mm}$ in diameter with a $2 \mathrm{~mm}$ central hole) were prepared and synovial tissue was placed in the central cavity. This allowed a standard tissue volume (approximately $4 \mathrm{mg}$ wet weight) and reproducible association between the synovial tissue to be obtained, which was more difficult for the porcine cocultures.

In most experiments the cartilage cultures or cocultures were maintained for eight days in a medium containing Dulbecco's modified Eagle's medium (DMEM; Gibco) and 5\% fetal calf serum (FCS) in a 5\% carbon dioxide/air incubator; $1 \mathrm{ml}$ of medium was used for each explant. For conventional cartilage cultures the medium was changed after four days and for cartilage/synovial tissue coculture the medium was replaced every two days. The medium was stored at $-20^{\circ} \mathrm{C}$ until analysed.

\section{RECOVERY EXPERIMENTS}

In these experiments porcine cartilage was cultured in the presence of hrIL-1 $\alpha$ (Genzyme Research, Norwalk, CT, USA) for four days and the recovery of the tissue during a further four days without hrIL-1 $\alpha$ was monitored. Tenidap (Pfizer Central Research, Sandwich, Kent, United Kingdom) or the non-steroidal anti-inflammatory drugs (NSAIDs) diclofenac or naproxen (Sigma, St Lous, MO, USA) were added either with the hrIL-1 $\alpha$ or in the recovery period. Tenidap was dissolved in dimethylsulphoxide to $5 \mathrm{mg} / \mathrm{ml}$ and diluted with DMEM plus 5\% FCS.

\section{ANALYTICAL METHODS}

The glycosaminoglycan (GAG) content of the tissue and medium was determined by the dimethylene blue technique ${ }^{23}$ after the tissue had been dried to constant weight and digested for two hours at $60^{\circ} \mathrm{C}$ in $1 \mathrm{ml}$ papain. A standard whale (Sigma) chondroitin sulphate preparation was used in each experiment.

RADIOCHEMICAL MEASUREMENTS

The synthesis of GAGs was estimated by the incorporation of sulphur-35 labelled sulphate $\left({ }^{35} \mathrm{SO}_{4}^{2-}\right.$ ) (Amersham International, United
Kingdom) during a 20 hour pulse, followed by papain digestion of the tissue and precipitation with cetyl pyridinium chloride onto filter paper for subsequent scintillation counting. $\left[{ }^{3} \mathrm{H}\right]$ Leucine (Amersham International) incorporation into trichloroacetic acid precipitable material was used to measure protein synthesis and $\left[{ }^{3} \mathrm{H}\right]$ glucosamine (Amersham International) incorporation into cetyl pyridinium chloride precipitable material was used as another measurement of GAG synthesis. In some experiments the synovial tissue was separated from the cartilage at the end of the experiment and pulsed with $\left[{ }^{3} \mathrm{H}\right]$ leucine as a measure of protein synthesis.

\section{STATISTICAL METHODS}

Significance was calculated using Student's $t$ test. An arcsine conversion was used for statistical evaluation of the percentage GAG retained in the tissue.

\section{Results}

DEGRADATION OF CARTILAGE MATRIX INDUCED BY hrIL- $1 \alpha$ AND BY SYNOVIAL TISSUE

Figure 1 shows that bovine cartilage in organ culture had a rapid turnover of matrix GAG and was susceptible to the action of hrIL- $1 \alpha$ (2 $\mathrm{ng} / \mathrm{ml}$ ) and to cocultivation with synovial tissue. Thus, although the controls contained $70 \%$ of the starting material after eight days in culture, in the presence of hrIL-1 $\alpha$ or synovial tissue this was reduced to only $8 \%$. Porcine cartilage (fig 2) had a lower GAG turnover rate; controls contained $86 \%$ of the GAG content after eight days in culture. Porcine cartilage was also less susceptible to the action of $\mathrm{hrIL}-1 \alpha$ and cocultivation with synovial tissue than bovine cartilage. The spontaneous GAG loss from porcine and bovine cartilage in culture was decreased significantly $(\mathrm{p}<0.001)$ by $20 \mu \mathrm{g} / \mathrm{ml}$ tenidap and $5-20$ $\mu \mathrm{g} / \mathrm{ml}$ tenidap gave significant $(\mathrm{p}<0.01)$ protection against GAG loss induced by hrIL-1 $\alpha$ in bovine and porcine cultures and porcine coculture. In addition, $10-20 \mu \mathrm{g} / \mathrm{ml}$ tenidap significantly $(\mathrm{p}<0 \cdot 01)$ protected bovine cocultures.

EFFECT OF TENIDAP ON CARTILAGE GAG SYNTHESIS IN THE PRESENCE OF SYNOVIAI TISSUE

Glycosaminoglycan synthesis, as measured by incorporation of ${ }^{35} \mathrm{SO}_{4}^{2-}$ into cetyl pyridinium chloride precipitable material in porcine and bovine cartilage was substantially inhibited in the presence of synovial tissue. Porcine cartilage showed a $70 \%$ inhibition of incorporation of ${ }^{35} \mathrm{SO}_{4}^{2-}$ into GAGs and bovine cartilage produced approximately a $60 \%$ inhibition. In the bovine cartilage cocultures the presence of mid-range concentrations of tenidap appeared to give a significant $(p<0.001)$ degree of protection against the inhibitory action of synovial tissue. This work was repeated to evaluate whether the effect could be confirmed and the protection was 


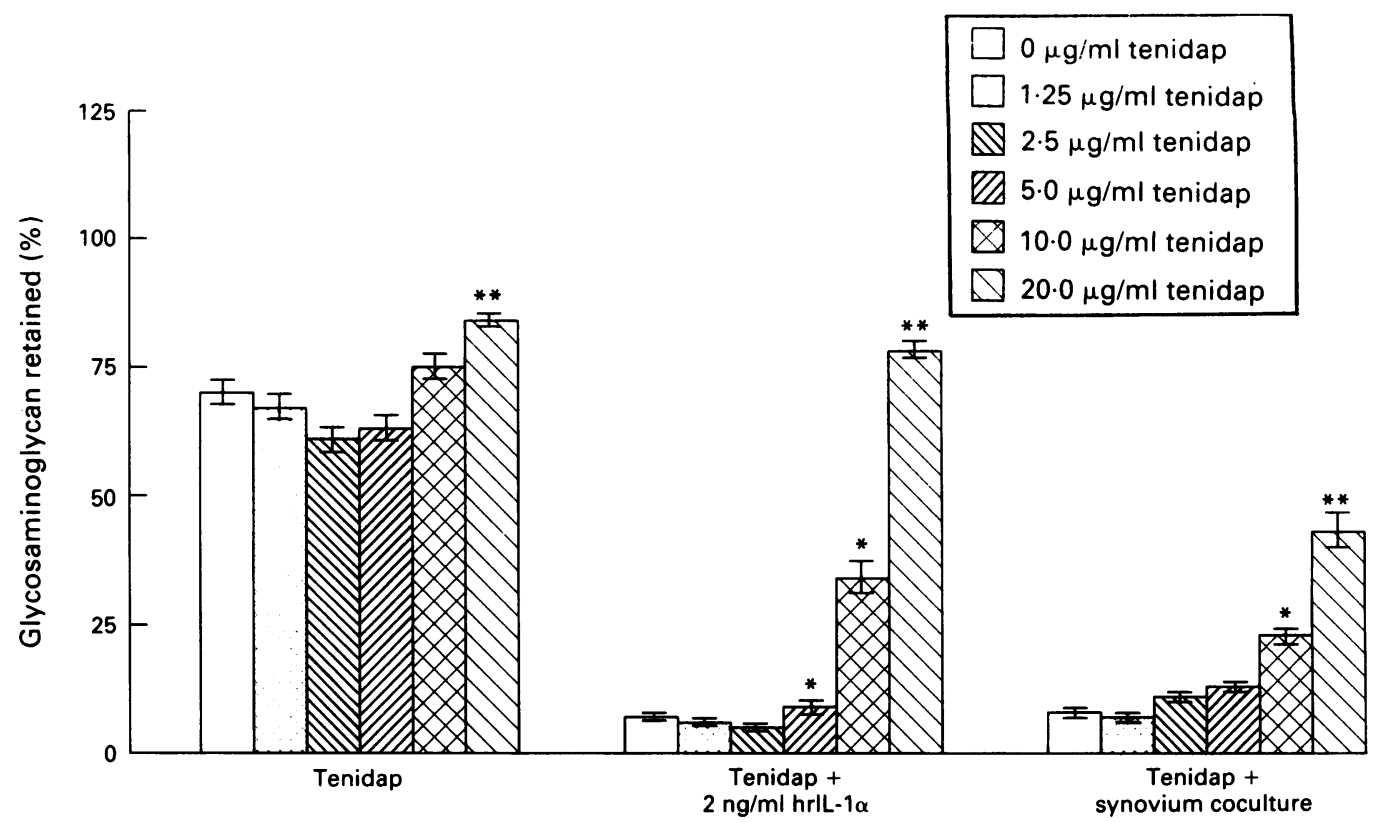

Figure 1 Effect of tenidap on human recombinant interleukin $1 \alpha(h r I L-1 \cdot \alpha)$ and synovial tissue mediated bovine cartilage degradation. Bovine cartilage discs (4 mm) were cultured in Dulbecco's modified Eagle's medium plus $5 \%$ fetal calf serum with or without $2 \mathrm{ng} / \mathrm{ml} \mathrm{hrIL-1 \alpha}$ for eight days. Cocultivation of bovine cartilage and $5 \mathrm{mg}$ symovial tissue was carried out using $4 \mathrm{~mm}$ annuli. Results are expressed as the percentage of glycosaminoglycan retained. Ten replicates were set up for each experimental condition. ${ }^{*}<0.01,{ }^{\star *} p<0.001$ compared with controls within the experimental group.

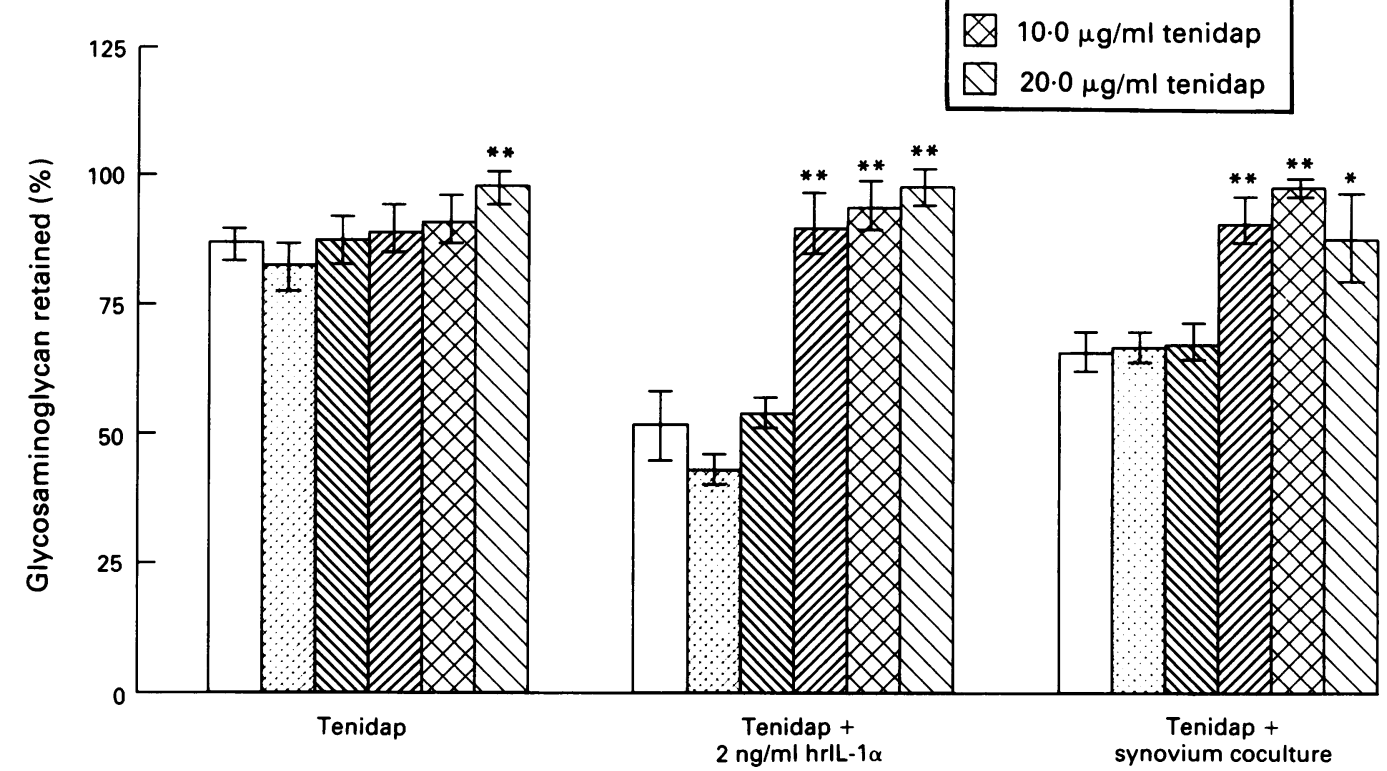

Figure 2 Effect of tenidap on human recombinant interleukin $1 \alpha(\mathrm{hrlL}-1 \alpha)$ and synovial tissue mediated porcine cartilage degradation. Porcine cartilage strips $(4 \times 2 \times 1 \mathrm{~mm})$ were cultured in Dulbecco's modified Eagle's medium plus $5 \%$ fetal calf serum with or without $2 \mathrm{ng} / \mathrm{ml} \mathrm{hrIL}-1 \alpha$ for eight days. Cocultivation of porcine cartilage strips and $5 \mathrm{mg}$ synovial tissue was carried out. Results are expressed as percentage of glycosaminoglycan retained. Ten replicates were set up for each experimental condition. ${ }^{*_{p}}<0.01,{ }^{*} \star_{p}<0.001$ compared with controls within the experimental group.

found to be statistically significant $(p<0.01)$ at $2.5 \mu \mathrm{g} / \mathrm{ml}$ tenidap. Porcine cartilage, on the other hand, did not show a statistically significant protective action of tenidap on the inhibition of cartilage synthesis by synovial tissue. The highest dose of the drug significantly $(p<0.001)$ inhibited porcine and, in one experiment, bovine cartilage ${ }^{35} \mathrm{SO}_{4}^{2-}$ incorporation. In the second experiment, this effect on bovine cartilage was not statistically significant.

Curiously, when $\left[{ }^{3} \mathrm{H}\right]$ glucosamine incorporation into cetyl pyridinium chloride precipitable material was measured, significant inhibition of synthesis was not seen at any dose of tenidap. Protein synthesis by porcine cartilage, as shown by the incorporation of $\left[{ }^{3} \mathrm{H}\right]$ leucine into cetyl pyridinium chloride precipitable 
material, showed a slight inhibition; significant only at the highest concentration.

EFFECT OF TENIDAP, DICLOFENAC, AND NAPROXEN ON THE INHIBITION OF GAG SYNTHESIS BY hrIL $-1 \alpha$

Figure 3 shows that $2 \mathrm{ng} / \mathrm{ml}$ hrIL- $1 \alpha$ produced between 75 and $85 \%$ inhibition of GAG synthesis in porcine articular cartilage. The effect of tenidap on this inhibition and a comparison of its effect with two NSAIDs (diclofenac and naproxen) is also shown. Tenidap, at 5 and $10 \mu \mathrm{g} / \mathrm{ml}$, gave statistically significant $(p<0.001)$ protection from the action of $2 \mathrm{ng} / \mathrm{ml} \mathrm{hrIL-1} \alpha$. The rate of ${ }^{35} \mathrm{SO}_{4}^{2-}$ incorporation was increased threefold in the presence of these concentrations of tenidap. This effect was not seen at $20 \mu \mathrm{g} / \mathrm{ml}$, a result consistent with these data. Neither diclofenac $(0 \cdot 1-1 \cdot 0 \mu \mathrm{g} / \mathrm{ml})$ nor naproxen $(12 \cdot 5-100$ $\mu \mathrm{g} / \mathrm{ml}$ ) showed any evidence of protection against the inhibitory effect of hrIL-1 $\alpha$. The concentration ranges chosen for these drugs were based on the known levels present in serum/synovial fluid during treatment of human disease. ${ }^{2425}$

EFFECT OF TENIDAP, DICLOFENAC, AND NAPROXEN ON GAG LOSS IN THE PRESENCE OF hrIL-1 $\alpha$

Figure 4 shows a comparison of the effects of tenidap, diclofenac, and naproxen on GAG retention in porcine cartilage treated with $2 \mathrm{ng} /$ $\mathrm{ml} \mathrm{hrIL-1} \alpha$. In this experiment tenidap showed significant $(p<0.01)$ inhibition of hrIL-1 $\alpha$ induced GAG loss at doses of $2 \cdot 5-20 \mu \mathrm{g} / \mathrm{ml}$. At $5 \mu \mathrm{g} / \mathrm{ml}$ tenidap protection, although significant $(p<0.01)$, was not as great as that seen in the previous experiment, whereas at the highest levels the results were similar to those seen in fig 2. Neither diclofenac nor naproxen gave any evidence of protection against GAG loss induced by the cytokine.

EFFECT OF TENIDAP ON SYNOVIAL METABOLIC ACTIVITY

As tenidap significantly protected articular cartilage against the damaging effects of synovial coculture, it was necessary to determine whether or not there was a direct action of the drug on synovial metabolism. It could be argued that if tenidap was toxic to synovial tissue this would prevent the secretion of degradative enzymes or cytokines. To test this, synovial tissue was cultured for eight days in the presence of tenidap and then pulse labelled with $\left[{ }^{3} \mathrm{H}\right]$ leucine for six hours in one experiment and for 20 hours in a second. In neither instance was there any evidence of inhibition of protein synthesis in the synovial tissue at any concentration of tenidap.

EFFECT OF TENIDAP ON THE CHONDROLYTIC ACTIVITY OF PORCINE CARTILAGE

Fell and $\mathrm{Jubb}^{21}$ were the first to show that the degradation of articular cartilage during coculture with synovium was due to two separate factors: activation of the indigenous chondrocytes and the effect of enzymes produced by the synovial tissue acting directly on the adjacent cartilage matrix. These two effects were separated by the use of dead cartilage in the coculture system which only responds to the direct action of the extrinsic proteinases. A similar experiment was

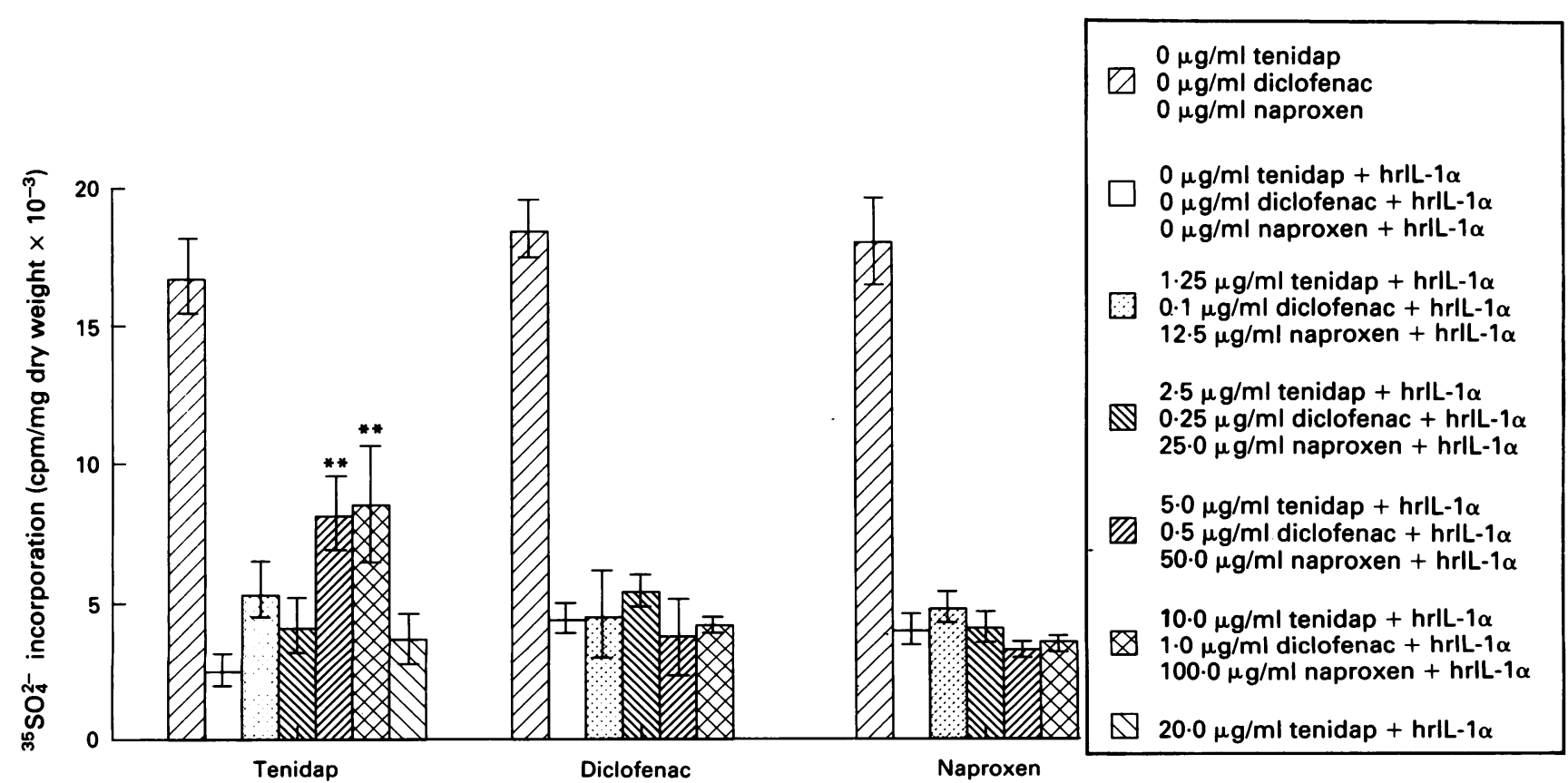

Figure 3 Effect of tenidap, diclofenac, and naproxen on porcine cartilage glycosaminoglycan synthesis in the presence of human recombinant interleukin $1 \alpha(\mathrm{hrIL}-1 \mathrm{\alpha})$. Porcine cartilage strips $(4 \times 2 \times 1 \mathrm{~mm})$ were cultured in Dulbecco's modified Eagle's medium plus $5 \%$ fetal calf serum in the interleukin $1 \alpha(\mathrm{hrIL}-1 \alpha)$. Porcine cartilage strips $(4 \times 2 \times 1 \mathrm{~mm})$ were cultured in Dulbecco's modified Eagle's medium plus $5 \%$ fetal calf serum in the
absence (control) or presence of $2 \mathrm{ng} / \mathrm{ml}$ hrlL-1 $\alpha$ and various concentrations of tenidap, diclofenac, and naproxen for eight days. At the end of the culture period tissues were pulsed for 20 hours with $185 \mathrm{kBq}$ sulphur-35 labelled sulphate $\left({ }^{35} \mathrm{SO}_{4}^{2-}\right)$. Results are expressed as counts/min per dry weight of cetyl pyridinium chloride precipitable material. Ten replicates were set up for each experimental condition. ${ }^{\star} p<0.01,{ }^{\star} p<0 \cdot 001$ compared with hrIL-1 $\alpha$ within the experimental group. 


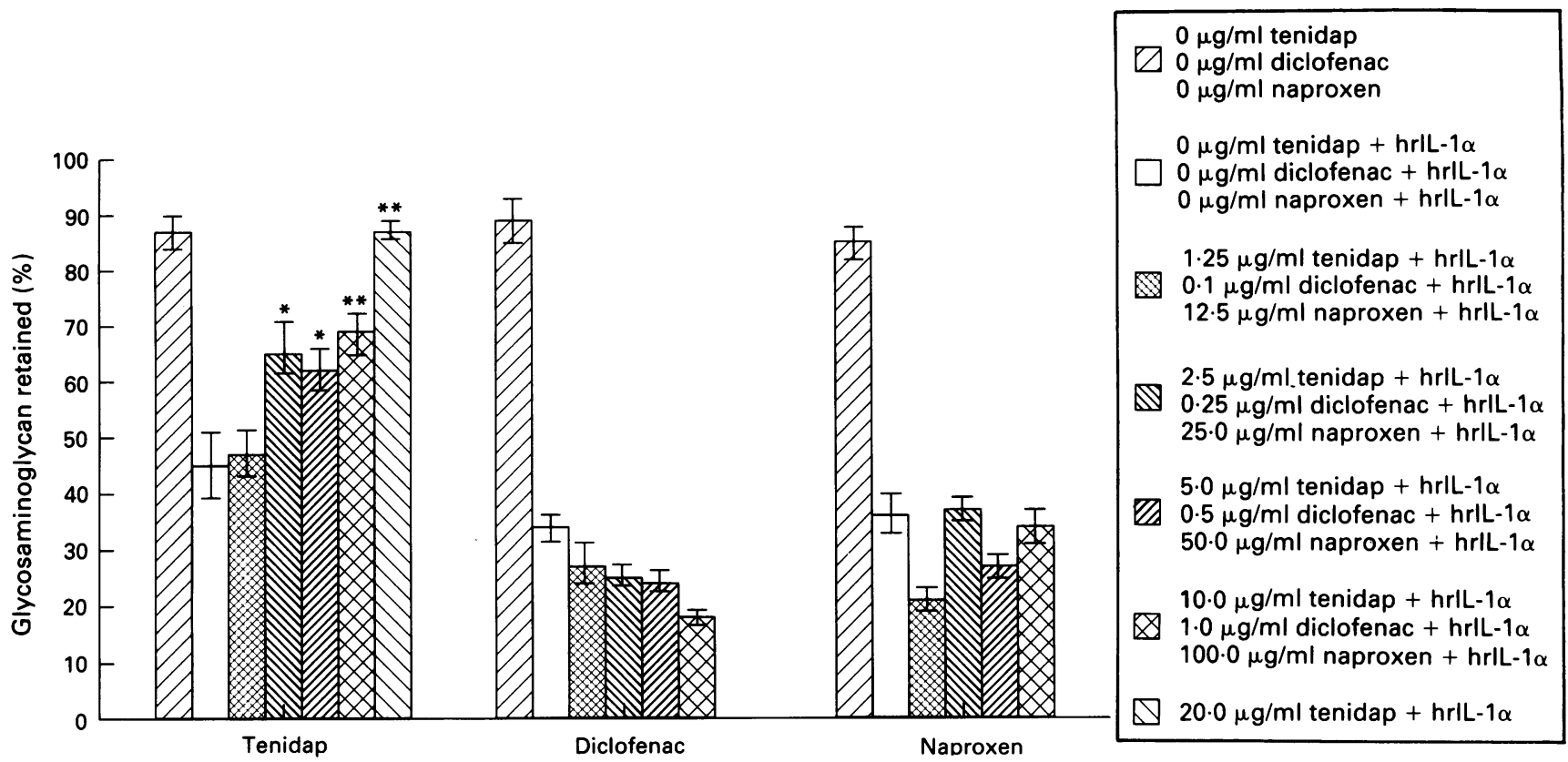

Figure 4 Effect of tenidap, diclofenac, and naproxen on porcine cartilage glycosaminoglycan loss in the presence of human recombinant interleukin $1 \alpha$ (hrIL-1 $\alpha)$. Porcine cartilage strips $(4 \times 2 \times 1 \mathrm{~mm})$ were cultured in Dulbecco's modified Eagle's medium plus $5 \%$ fetal calf serum in the absence (control) or presence of $2 \mathrm{ng} / \mathrm{ml} \mathrm{hrIL-1 \alpha}$ and various concentrations of tenidap, diclofenac, and naproxen for eight days. Results are expressed as the percentage of glycosaminoglycan retained in the tissue. Ten replicates were set up for each experimental condition. ${ }^{\star} p<0 \cdot 01,{ }^{\star} p<0 \cdot 001$ compared with hrIL-1 $\alpha$ within the experimental group.

therefore carried out with tenidap treated synovial tissue and the chondrolytic activity was monitored by the loss of GAG from adjacent, but dead, porcine articular cartilage. In this experiment approximately three times as much synovial tissue was used as in the live cocultures. Figure 5 shows that tenidap gave substantial protection to the cartilage, indicating that the production of chondrolytic enzymes by the synovium could be modulated by the drug. The effect of tenidap was highly significant $(\mathrm{p}<0.001)$ from 1.25 to $20 \mu \mathrm{g} / \mathrm{ml}$.

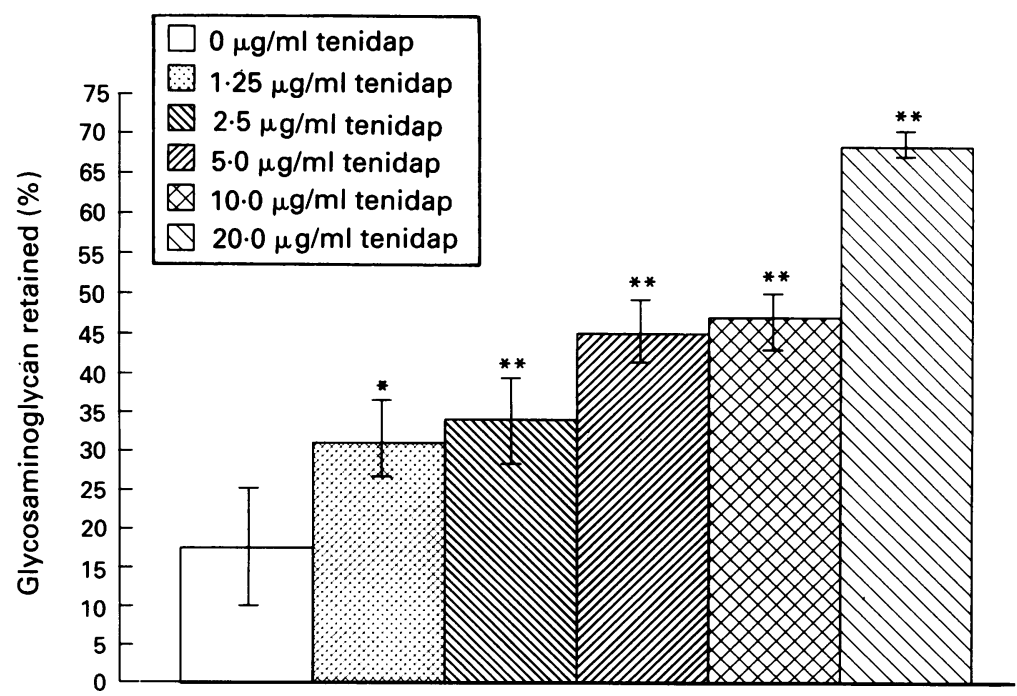

Figure 5 Effect of tenidap on porcine synovial metabolic activity (chondrolysis). Dead porcine cartilage strips ( $4 \times 2 \times 1 \mathrm{~mm}$, frozen and thawed three times) were cultured with $15 \mathrm{mg}$ synovium in Dulbecco's modified Eagle's medium plus $5 \%$ fetal calf serum for eight $15 \mathrm{mg}$ synovium in Dulbecco's modified Eagle's medium plus $5 \%$ fetal calf serum for eight replicates were set up for each experimental condition. ${ }^{*_{p}}<0.01,{ }^{\star}{ }_{p}<0.001$ compared. with controls.
EFFECT OF TENIDAP, DICLOFENAC, AND NAPROXEN ON THE RECOVERY OF CARTILAGE AFTER DAMAGE INDUCED BY hrIL- $1 \alpha$

In these experiments porcine articular cartilage was treated with $2 \mathrm{ng} / \mathrm{ml} \mathrm{hrIL}-1 \alpha$ for four days, either with or without tenidap, diclofenac, or naproxen, and then cultured for a further four days without hrIL-1 $\alpha$, with or without the drug. The parameters of recovery were the GAG content of the tissue and the ${ }^{35} \mathrm{SO}_{4}^{2-}$ incorporation into GAG as a measure of chondrocyte matrix synthetic activity. As a preliminary to these experiments, the effect of tenidap on untreated cartilage medium for a further four days was investigated. Figure 6 shows that tenidap did not significantly influence the GAG content of the tissue during this experimental procedure. There was, however, a statistically significant $(p<0.01)$ increase in the synthetic activity of the cartilage as expressed by the incorporation of ${ }^{35} \mathrm{SO}_{4}^{2-}$ at the higher concentrations of the drug (5-20 $\mu \mathrm{g} / \mathrm{ml})$; an observation which should be compared with the data in fig 7 .

In the first hrIL-1 $\alpha$ experiment the tissue was treated with $2 \mathrm{ng} / \mathrm{ml} \mathrm{hrIL-1} \alpha$ for four days and tissue was then cultured in control medium without hrIL-1 $\alpha$ but in the presence of various concentrations of tenidap. Figure 7A shows that, at between 2.5 and $5 \mu \mathrm{g} / \mathrm{ml}$ tenidap, there was a marked increase in the synthetic activity of the tissues compared with controls, and this was reflected in the increased GAG concentrations. This effect on synthesis was not seen at the highest concentration of the drug $(20 \mu \mathrm{g} / \mathrm{ml})$. In the second recovery experiment the tissue was treated with hrIL-1 $\alpha$ plus tenidap at various concentrations for four days to determine whether the protective action of tenidap would also modify the 

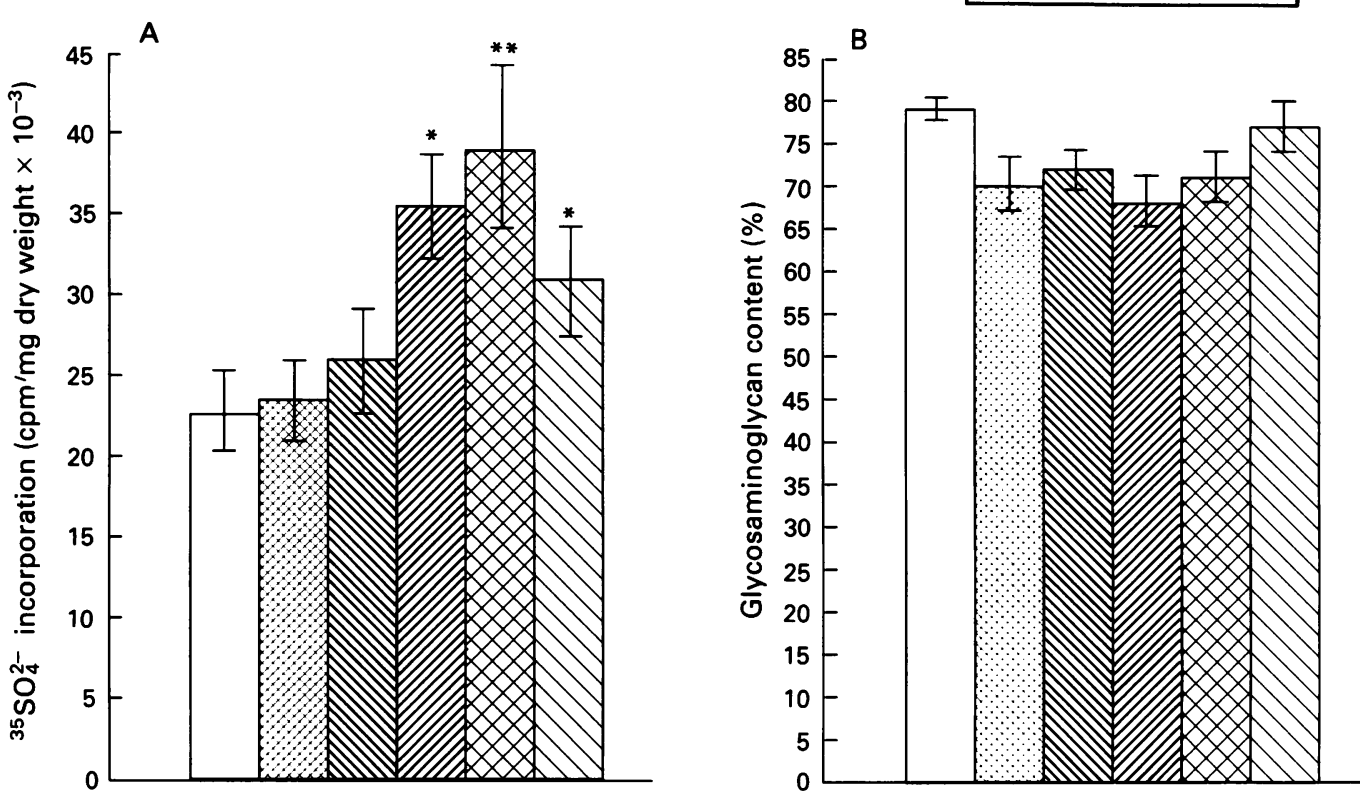

Figure 6 Metabolic activity of porcine cartilage strips after incubation with tenidap. Porcine cartilage strips $(4 \times 2 \times 1 \mathrm{~mm})$ were cultured with Dulbecco's modified Eagle's medium plus $5 \%$ fetal calf serum in the presence of tenidap for four days. Explants were then transferred to medium without tenidap and cultured for a further four days. (A) Incorporation of sulphur-35 labelled sulphate into $\left({ }^{35} \mathrm{SO}_{4}^{2-}\right)$ cetyl pyridinium chloride precipitable material and $(B)$ percentage of glycosaminoglycan retained. Ten replicates were set up for each experimental condition. ${ }^{*} p<0 \cdot 01$, $\star_{p}<0.001$ compared with controls within experimental group.
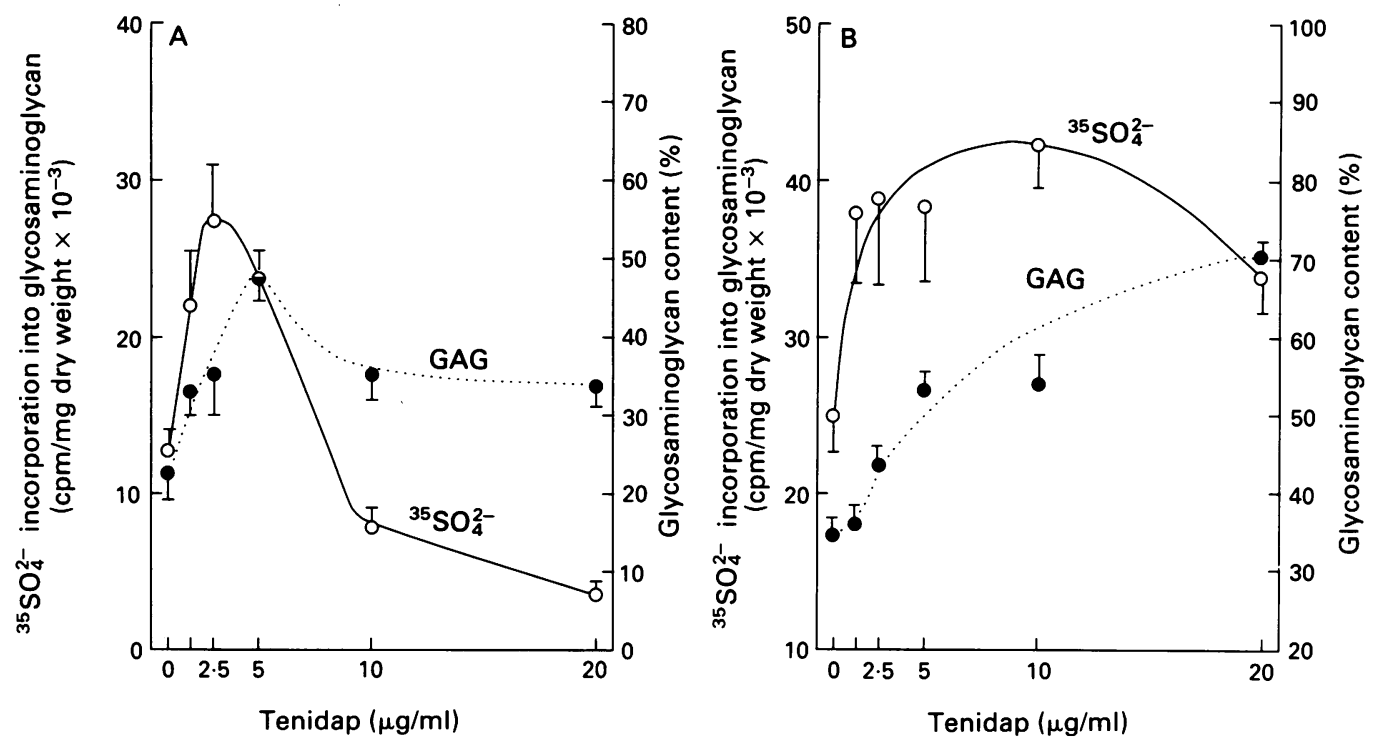

Figure 7 Effect of tenidap on recovery of porcine cartilage after human recombinant interleukin $1 \alpha(\mathrm{hrIL}-1 \alpha)$ induced damage. Porcine cartilage strips $(4 \times 2 \times 1 \mathrm{~mm})$ were cultured with Dulbecco's modified Eagle's medium plus $5 \%$ fetal calf serum for four days in the presence of $(A) 2 \mathrm{ng} / \mathrm{ml} \mathrm{hrIL-1 \alpha}$ and no tenidap, or $(B) 2 \mathrm{ng} / \mathrm{ml} \mathrm{hrIL}-1 \alpha$ and various concentrations of tenidap. Explants were then transferred to medium $(A)$ without hrIL-1 $\alpha$ but with tenidap, or (B) without hrIL-1 $\alpha$ or tenidap, and cultured for a further four days. Incorporation of sulphur-35 labelled sulphate into cetyl pyridinium chloride precipitable material and glycosaminoglycan (GAG) content were measured. Ten replicates were set up for each experimental condition.

recovery of the tissue after the action of hrIL-1 $\alpha$. It can be seen from fig 7B that at all concentrations of the drug there was more GAG in the cartilage and that this was greatest at the highest concentration. The incorporation of ${ }^{35} \mathrm{SO}_{4}^{2-}$ also showed a significant increase in synthetic activity over the middle dose range of tenidap. As the pulse period in these experiments was carried out at the end of the culture period-that is, at eight 
days, these results reflect the activity after four days of recovery. This indicates that tenidap, certainly in the middle dose range, appeared to improve the recovery of the tissue after hrIL-1 $\alpha$ insult.

Naproxen and diclofenac were tested under the same experimental conditions but neither drug had any influence on recovery in terms of the GAG content of the tissue or the rate of ${ }^{35} \mathrm{SO}_{4}^{2-}$ incorporation, unlike the results seen with tenidap.

\section{Discussion}

These experiments were undertaken to determine whether it was possible to modulate cartilage damage. In vitro organ culture techniques were chosen because it has been shown that the reactions of intact cartilage in organ culture correspond closely to those seen in animal experiments. For example, hrIL$1 \alpha$, which increases chondrocyte catabolic reactions and inhibits chondrocyte matrix synthetic mechanisms, will, when administered in vivo, produce similar results. ${ }^{13}$

The two in vitro methods of inducing cartilage damage, namely hrIL-1 $\alpha$ treatment and coculture with synovial tissue, were used because it was considered that the cytokine had a direct role in the mechanism of cartilage damage in osteoarthritis and also as part of the complex modulation system for the synovial inflammation characteristic of rheumatoid arthritis. ${ }^{1-4} 6$ In inflammatory arthritis the catabolism of articular cartilage is believed to be due to the activation of the indigenous chondrocytes and to the action of extrinsic proteolytic enzymes and possibly free radicals from the adjacent synovial tissue. The synovial/ cartilage cocultures were developed by Fell and $\mathrm{Jubb}^{21}$ as an in vitro model for this effect. Although these types of catabolic reactions have been extensively studied, the observation that human articular cartilage synthesis is susceptible to inhibition by low doses of hrIL- $1 \alpha$ and by certain NSAID ${ }^{14}$ must be considered in the formulation of treatment strategies for chronic rheumatic disease. It seems likely that not all NSAIDs have the same pharmacological properties in terms of cartilage damage. It is important to determine whether any new antiarthritic drug should, at least, not prevent the active repair processes that are possible. ${ }^{1213}$ For this reason the present experimental work not only compared the action of tenidap-a new cytokine modulating antirheumatic drug-with the NSAIDs diclofenac and naproxen directly on cartilage metabolism, and on the modulation of hrIL- $1 \alpha$ activity, but also investigated the repair of articular cartilage after hrIL-1 $\alpha$ induced damage in the presence of the three drugs.

The experiments confirmed that, in the two species tested, hrIL-1 $\alpha$ and synovial tissue caused the degradation of cartilage matrix and inhibited matrix synthesis. Tenidap was shown to give substantial and significant protection against the catabolic effect of hrIL-1 $\alpha$. There was, to a lesser degree, some protective effect in the middle dose range against the inhibition of synthetic activity by hrIL-1 $\alpha$ and by synovial tissue. At the highest dose of tenidap tested there was inhibition of ${ }^{35} \mathrm{SO}_{4}^{2-}$ incorporation into GAGs, but curiously this effect was not confirmed when $\left[{ }^{3} \mathrm{H}\right]$ glucosamine was used as a marker of GAG synthesis. Neither of the two NSAIDs tested had any protective action on the integrity of the cartilage matrix nor on the ability of chondrocytes to synthesise GAG in the presence of hrIL-1 $\alpha$. Tenidap showed some beneficial effect when recovery after hrIL- $1 \alpha$ treatment was studied, either when administered together with the hrIL- $1 \alpha$, or subsequently. Normal tissue treated with tenidap and then allowed to metabolise in the absence of the drug showed no deleterious effects, even at the highest concentration of tenidap. The optimum tenidap concentration for protection against hrIL- $1 \alpha$ and for encouraging recovery from the damaging effects of the cytokine, without itself inhibiting synthesis, appears to be between 5 and 10 $\mu \mathrm{g} / \mathrm{ml}$ in these animal cartilages. This narrow band suggests that careful dose control would be needed to obtain this effect in vivo.

Caution must be exercised in any extrapolation from in vitro to in vivo situations and from work on animal cartilage to possible effects on human cartilage. In particular, the lack of catabolic action of IL-1 on human cartilage $^{26}$ suggests that the drug's action on matrix synthesis is of greater importance than the inhibition of catabolism. It seems possible that if concentrations of tenidap between 5 and $10 \mu \mathrm{g} / \mathrm{ml}$ in the synovial fluid can be achieved (synovial fluid concentrations in this range have been observed during treatment of patients with daily doses of $120 \mathrm{mg}^{27}$ ), this could have an action on the inhibition of matrix synthesis by hrIL-1 $\alpha$, thus allowing natural repair processes to take place.

In addition to its reported activity in decreasing hrIL-1 $\alpha$ production by macrophages and monocytes, ${ }^{18}{ }^{19}$ tenidap has three potentially useful functions in the modulation of articular damage. Firstly, tenidap may prevent the action of cytokines in causing cartilage catabolism in some patients. Secondly, tenidap may be useful in increasing the synthetic and repair activities of damaged cartilage. Finally, from the coculture experiments, it appears that tenidap may modulate the release of chondrolytic enzymes from adjacent synovial tissue. ${ }^{28}$ The last result suggests the possibility that tenidap could modulate disease activity in inflammatory arthritis where pannus erosion of cartilage plays a significant part in joint damage. The absence of activity observed with diclofenac and naproxen implies that the prevention of chondrolysis shown in the presence of tenidap was not a result of inhibition of cyclo-oxygenase. The inhibition of IL-1 $\alpha$ bioactivity previously reported using tenidap, perhaps mediated via 5-lipoxygenase inhibition, may account for the activity of tenidap observed in this study. Current experimental work using the drug on normal and osteoarthritic human cartilage and rheumatoid arthritis synovium in organ culture may help to resolve these questions. 
1 Dingle J T. Recent studies on the control of joint damage. Ann Rheum Dis 1979; 38: 201-14.

2 Mizel S B. Interleukin, immunity and inflammation. In: Glauert A M, ed. The control of tissue damage. Amsterdam: Elsevier, 1988: 69-75.

3 Saklatvala J. Tumour necrosis factor stimulates resorption and inhibits synthesis of proteoglycan in cartilage. Nature 1986; 322: 547-9.

4 Krane S M, Dayer J-M, Simon L S, Byrne S. Mononuclear cell-conditioned medium containing mononuclear cell factor homologous with interleukin 1 stimulates collagen and fibronectin synthesis by adherent rheumatoid synovial cells: effects of prostaglandin $E_{2}$ and indomethacin. Collagen Related Research 1985; 5: 99-117.

5 Saklatvala J, Curry V A, Sarsfield S J. Purification to homogeneity of pig leucocyte catabolin, a protein that causes cartilage resorption in vitro. Biochem $\mathcal{f} 1983$; 215: 385-92.

6 Dinarello C A. Interleukin 1: amino acid sequences, multiple biological activities and comparison with tumour necrosis factor (cachectin). In: Cruse J M, Lewis RE, eds. The year in immunology. Vol. 2. Basle: Karger, 1986: The year

7 Bird T A, Saklatvala J. Identification of a common class of high-affinity receptors for both types of porcine interleukin 1 on connective tissue cells. Nature 1986; 324: 263-6.

8 Tyler $\mathrm{J}$ A. The influence of interleukin 1 and insulin-like growth factor 1 on the integrity of cartilage matrix. In Glauert A M, ed. The control of tissue damage. Amsterdam: Elsevier, 1988: 197-219.

9 Dingle J T. The effect of synovial catabolin on cartilage synthetic activity. Connect Tissue Res 1984; 12: 277-86.

10 Tyler J A. Articular cartilage cultured with catabolin (pig interleukin 1) synthesizes a decreased number of norm proteoglycan molecules. Biochem $f$ 1985; 277: 869-78.

11 Tyler J A. Chondrocyte-mediated depletion of articulated cartilage proteoglycans in vitro. Biochem $\mathcal{f} 1985$; 225: 493-507.

12 Nakata K, Bullough P G. The injury and repair of human articular cartilage: a morphological study of 192 cases of osteoarthritis. Fournal of the fapanese Orthopaedic Association 1986; 60: 763-75.

13 Page Thomas D P, King B, Stephens T, Dingle J T. In vivo studies of cartilage regeneration after damage induced by catabolin/IL-1. Ann Rheum Dis 1991; 50: 75-82.

14 Brandt K D. Effects of non-steroidal anti-inflammatory drugs on the metabolism in vitro and in vivo. $A m \mathcal{F} M e d$ 1987; 83: 29-34.

15 Herman J H, Appel A M, Khosla R C, Hess E V. In vitro effects of select non-steroidal anti-inflammatory drugs on the synthesis and activity of anabolic regulatory factors produced by osteoarthritic and rheumatoid synovial tissue. $\mathcal{F}$ Rheumatol 1989; 16: 75-81.

16 Hess E V, Herman J H. Cartilage metabolism and antiinflammatory drugs in osteoarthritis. Am $\mathcal{F}$ Med 1986; 81 (suppl 5B): 36-43

$17 \mathrm{Kalben}$ D A. The influence of NSAIDs on morphology of articular cartilage. Scand $\mathcal{F}$ Rheumatol Suppl 1989; 77: articular

18 McDonald B, Loose L, Rosenwasser L J. The influence of a novel arachidonate inhibitor, CP-66,248 on the production and activity of human monocyte IL-1. Arthriti Rheum 1988; 31 (suppl 4): S17.

19 Otterness I G, Bliven M L, Downs J T, Hanson D C. Effect of CP-66,248 on IL-1 synthesis by murine peritoneal macrophages. Arthritis Rheum 1988; 31 (suppl 4): S90.

20 Dingle J T, Horsfield P, Fell H B, Barratt ME J. Breakdown of proteoglycan and collagen induced in pig articular cartilage in organ culture. Ann Rheum Dis 1975; 34 303-11.

21 Fell $\mathrm{H} \mathrm{B}$, Jubb $\mathrm{R}$ W. The effect of synovial tissue on the breakdown of articular cartilage in organ culture. Arthritis Rheum 1977; 20: 1359-63.

22 Dingle J T. The role of neutral and acid proteinases in connective tissue turnover in proteoglycan and physiological regulation. tissue turnover in proteoglycan and physiologica

23 Farndale R W, Sayers C A, Barrett A J. A direct spectrophotometric microassay for sulfated glycosaminoglycan in cartilage culture. Connect Tissue Res 1982; 9: 247-8.

24 Fowler P D, Shadforth M F, Crook P R, John V A. Plasm and synovial fluid concentrations of diclofenac sodium and its major hydroxylated metabolites during long term treatment of rheumatoid arthritis. Eur $f$ Clin Pharmacol 1983; 25: 389-94.

25 Jalava S, Saarimaa H, Anttila M, Sundquist H. Naproxen concentrations in serum, synovial fluid and synovium. Scand $¥$ Rheumatol 1977; 6: 155-7.

26 Dingle J T. NSAIDs and human cartilage metabolism. In Rainsford K D and Velo G P, eds. Side-effects of antiinflammatory drugs. London: Kluwer, 1992: 261-8.

27 Blackburn W D, Heck L W, Loose L D, Eskra J, Carty T J Inhibition of 5 -lipoxygenase product formation and Inhibition of 5-lipoxygenase product formation and polymorphonuclear cell degranulation by tenidap sodium in patients with

28 Sipe J D, Bartle L M, Loose L D. Modification of proinflammatory cytokine production by the antirheumatic agents tenidap and naproxen. A possible correlate with clinical acute phase response. I Immunol 1992; 148 $480-4$ 